Med Princ Pract 2013;22:605

DOI: $10.1159 / 000348476$

\section{Comment on 'Epicardial Adipose Tissue Increased in Patients with Newly Diagnosed Subclinical Hypothyroidism'}

\section{Murat Atalay}

Merzifon Military Hospital, Merzifon, Turkey

\section{Dear Editor,}

I read with great interest the study of Korkmaz et al. [1] entitled 'Epicardial adipose tissue increased in patients with newly diagnosed subclinical hypothyroidism'. The authors investigated the relationship between epicardial fat tissue thickness and subclinical hypothyroidism and reported that the epicardial fat tissue thickness was greater in patients with subclinical hypothyroidism than in control subjects. This cross-sectional study is noteworthy because of its interest and potential usefulness in clinical practice. However, I would like to comment on two points. Firstly, authors calculated the epicardial fat tissue thickness using an echocardiographic technique. Although several studies have been conducted with this technique, echocardiography measurement is not the gold standard for calculating epicardial tissue thickness. Epicardial adipose tissue thickness is most precisely quantified by MRI or CT imaging, and thickness of

\section{Reply}

Levent Korkmaz a, Sinan Sahin ${ }^{\text {b }}$, Ali Riza Akyuza, Murat Ziyrek ${ }^{b}$, Inan Anaforogluc, Mustafa Kosec, Hakan Erkan a, Mustafa Tarık Ağaça , Zeydin Acar ${ }^{\mathrm{a}}$

aDepartment of Cardiology, Ahi Evren Thoracic and Cardiovascular Surgery Training and Research Hospital, and Departments of ${ }^{b}$ Cardiology and 'Endocrinology, Trabzon Numune Training and Research Hospital, Trabzon, Turkey

\section{Dear Sir,}

We read with great interest the letter regarding our study entitled 'Epicardial adipose tissue increased in patients with newly diagnosed subclinical hypothyroidism' [1]. In this study, we aimed to test the hypothesis that patients with subclinical hypothyroidism might have increased epicardial fat that could have a potential role for increased cardiovascular events in this population. We certainly agree with Dr. Atalay that MRI or CT imaging provides better evaluation of epicardial fat than echocardiography. Due to ethical issues such as radiation exposure and the cost of CT and MRI imaging, we could not use these methods. In addition, although epicardial fat in the atrioventricular groove has been shown to provide a more accurate assessment of its atherogenic risk [2]. I think that this should have been stated as a limitation. Secondly, there are studies that show the relationship between epicardial fat tissue thickness and metabolic syndrome $[3,4]$. I think that the authors should have included this relationship in the Discussion section, this would have added more value to the results of their study.

I congratulate the authors for their original investigation and hope it will be a pioneer for studies of this type.

\section{References}

1 Korkmaz L, Sahin S, Akyuz AR, et al: Epicardial adipose tissue increased in patients with newly diagnosed subclinical hypothyroidism. Med Princ Pract 2013;22:42-46.

2 Wang TD, Lee WJ, Shih FY, et al: Association of epicardial adipose tissue with coronary atherosclerosis is region-specific and independent of conventional risk factors and intra-abdominal adiposity. Atherosclerosis 2010;213:279-287.

-3 Meijs MF, van der Graaf Y, Doevendans PA, et al: Quantification of epicardial and peri-coronary fat using cardiac computed tomography; reproducibility and relation with obesity and metabolic syndrome in patients suspected of coronary artery disease. Atherosclerosis 2008;197:896-903.

-4 Yerramasu A, Dey D, Venuraju S, et al: Increased volume of epicardial fat is an independent risk factor for accelerated progression of sub-clinical coronary atherosclerosis. Atherosclerosis 2012;220:223-230.

Murat Atalay

Merzifon Military Hospital, Merzifon, Amasya 05300 (Turkey)

E-Mail muratatalay@yahoo.com

echocardiography is not considered the gold standard for assessment of epicardial adipose tissue, it is widely accepted and used in clinical studies [2-5].

\section{References}

$>1$ Korkmaz L, Sahin S, Akyuz AR, et al: Epicardial adipose tissue increased in patients with newly diagnosed subclinical hypothyroidism. Med Princ Pract 2013;22:42-46.

2 Iacobellis G, Willens HJ: Echocardiographic epicardial fat: a review of research and clinical applications. J Am Soc Echocardiogr 2009;22:13111319.

-3 Nabati M, Saffar N, Yazdani J, Parsaee MS: Relationship between epicardial fat measured by echocardiography and coronary atherosclerosis: a single-blind historical cohort study. Echocardiography 2013, doi: 10.1111/echo. 12083

4 Jeong JW, Jeong MH, Yun KH, et al: Echocardiographic epicardial fat thickness and coronary artery disease. Circ J 2007;71:536-539.

5 Ahn SG, Lim HS, Joe DY, et al: Relationship of epicardial adipose tissue by echocardiography to coronary artery disease. Heart 2008;94:e7.

Levent Korkmaz, MD, Department of Cardiology

Ahi Evren Thoracic and Cardiovascular Surgery

Training and Research Hospital, Trabzon 61010 (Turkey)

E-Maill.korkmaz@yahoo.com

\section{KARGER}

E-Mail karger@karger.com www.karger.com/mpp

\section{(c) 2013 S. Karger AG, Base} 1011-7571/13/0226-0605\$38.00/0 Karger
Open access

This is an Open Access article licensed under the terms of the Creative Commons Attribution-NonCommercial 3.0 Unported license (CC BY-NC) (www.karger.com/OA-license), applicable to the online version of the article only. Distribution permitted for non-commercial purposes only. 